\title{
Contesting the Iranian Revolution as a turning-point discourse in Bahraini contentious politics
}

By Marc Owen Jones

This chapter contends that there is an overemphasis in the academic literature on the effect the Iranian Revolution had on shifting the dynamics of contentious politics in Bahrain. This has created a discourse in which belligerents are framed according to the contemporary transatlantic antipathy towards Iran, reifying a narrative that can contribute to the perpetuation of anti-Shi'a and anti-Bahāarna ${ }^{1}$ prejudice. Using a closer reading of historical and modern sources, this paper argues that it was not solely the Islamic Revolution, nor the discovery of the Islamic Front for the Liberation of Bahrain, that shifted government policy towards Bahrain's Shi'a. Instead, ethno-religious discrimination is rooted in the Al Khalifa legacy of conquest, which was ossified by colonial intervention, but reinvigorated by Bahrain's Independence, growing Saudi influence, the Iran-Iraq war, and a historically-rooted Al Khalifa antipathy towards the indigenous population. Thus, changes in the modalities of repression are better explained by a multitude of interacting factors, rather than the totalising influence of Iran.

In the writing of history, certain tropes can attract a certain amount of importance, becoming uncritically accepted and embedded in the abridged histories or summaries of specific nations or places. For Bahrain, the Iranian Revolution and the attempted coup of 1981 by the Islamic Front for the Liberation of Bahrain (IFLB) have become such tropes, and are often referred to as turning points in Bahrain's history of contentious politics. This has been exacerbated by Bahrain's limited sovereignty and reliance on foreign protectors, which have encouraged analyses of the role of transnational forces and links. Indeed, scholars, academics, and commentators, and I include myself among them, repeat the Islamic Revolution ad nauseum when recounting notable incidents of Bahrain's history. Arguably such a trend reflects what Edward Said noted was a superficial reporting of Iran, conducted by 'individuals connected to corporate or quasi-governmental institutions, or Middle Easterners known 
for their essentially antagonistic positions on the Iranian Revolution'. ${ }^{2}$ This coverage of the revolution and its immediate aftermath perhaps better reflect hurt sensibilities regarding the deposing of the US-backed shah, rather than the complexities of the regional situation.

Yet revisionism on this issue should be prompted, not simply by the topic of this collection, which asks, among other things, how historical events and transnational dynamics have shaped communal and ideological struggles within the Gulf, but also in consideration of contemporary facts. Following extensive scrutiny of the recent unrest by academics, NGOs, human rights organizations and social and traditional media, the Bahraini government's rhetoric about the Iranian sponsorship of the 2011 Uprising has been thrown into serious doubt. It is generally accepted that despite the Government of Bahrain's attempts to claim Iranian involvement behind the pro-democracy movement of $2011^{3}$, no substantive evidence has been found. ${ }^{4}$ On the contrary, analyses have shown that the government of Bahrain has employed PR companies to deliberately exaggerate the claim of Iranian involvement. ${ }^{5}$ Indeed, with the Government of Bahrain known to have deliberately instrumentalised sectarian relations as a divide and rule strategy in the recent Uprising $^{6}$, the discrediting of attempts to invoke Iranian-backing should prompt a re-evaluation of an often uncritically embraced assumption of Iranian agency in Bahraini politics throughout the early 1980s. Could it be that that the 1979 Revolution as-a-turning-point discourse is also a specious foundation on which current denouncements of the opposition lie? Has the emphasis in both media discourse and history itself come to represent an inaccurate and exaggerated distal shift in Bahrain's history? By reviewing the historical record, I argue that there were other significant, but poorly understood, factors during the 1970s and 1980s that resulted in both the increasing oppression of the 'religious' and non-religious opposition. Furthermore, the weight given to the Islamic Revolution in Bahrain outweighs its significance as the proximate cause in altering the modalities of repression and the treatment of Shi'a in Bahrain. Placing the cart before the horse is both inaccurate and damaging. Not only does it misplace causality for ideological reasons, but it has averted attention from exploring other important factors, such as a fundamentally discriminatory political system. 


\section{Metanarrative of the Revolution as turning-point discourse}

The Iranian Revolution as a turning point in Bahraini politics narratives tend to abrogate local agency or more complex explanations in favour of a simplified Iran-as-abogeyman analysis. As a result, it has become a recurring theme within national security rhetoric in Bahrain aimed at legitimising the persecution of the country's Shi'a population by emphasising their disputed allegiance to Bahrain. It has also served to support the hegemonic status quo by reinforcing the notion that the Government's oppression of the opposition is done so in order to maintain stability, plurality and sovereignty in the wake of an enduring transnational theocratic threat. ${ }^{7}$ Over emphasising the importance of the Islamic Revolution in Bahrain's history therefore underpins government strategies, processes, and actions that serve to disproportionally criminalise or 'securitise' (to use the fashionable nomenclature) the Shi'a members of society, while obscuring the roots of this discrimination. This, in turn, assists in the attribution of 'inferiority and/or radical alienness' of the Shi'a as Other, or outgroup, ${ }^{8}$ thereby perpetuating cycles of discrimination. Not only is this 'othering' regionally embedded, but it is also undoubtedly aggravated by Western hostility towards Iran which, as Shireen Hunter argues, has played a major role in causing people to overlook atrocities and injustices committed against Shi'a populations across the globe. ${ }^{9}$ To be clear, there is a difference between arguments of the impact of the Iranian Revolution in Bahrain, and the manner in which the Revolution was instrumentalised as a strategy of control. Indeed, it is certainly true that Bahrain's Rulers have invoked the Revolution 'to win the reflexive support of ordinary Sunnis and to diffuse citizen pressure for a political opening'. ${ }^{10}$ This argument, however, is different from overstating the actual effects on the beliefs of Bahrainis.

The turning-point narrative is pervasive in academic, policy, media and legal literature on Bahrain. In general, the perception of the post-1979 Iranian Government as a rogue actor in the international system, along with its well-publicised desire to 'export' the revolution, has facilitated the analysis of it as a causal fulcrum and archvillain in regional politics. This perception has been augmented since the invasion of 
Iraq and subsequent civil war in 2003, and popularised more recently by scholars such as Vali Nasr, who repeatedly refers the Revolution as a Shia 'awakening'. In The Shia Revival, Nasr writes 'The revolution also awakened the Shia. They became bolder in their demands for rights and representation, secure in the belief that Khomeini would support them and that they had a model for political activism which would succeed in challenging authority'. ${ }^{11}$ Nowadays, it is difficult to read the historical context of any piece on Bahrain without coming across the coup attempt or the Iranian Revolution as a variable in shifting the modality of Shi'a mobilization or threat perception ${ }^{12}$. This occurs across disciplines, from international relations to political science, with various levels of reductionism. Maximillian Terhalle sees the Iranian Revolution as the starting point of 'sectarianism' as a ruling strategy: 'The government has applied sectarianism as one of the means to rule the country since $1979 \ldots$ however, in the years before the revolution in Iran, the rulers had not taken advantage of sectarian divisions'. ${ }^{13}$ Afshin Shahi infers a more ubiquitous appeal of the revolution to all Shi'a, irrespective of marja' taqlīdī (source to imitate and/or follow): 'The wind of [the] Iranian revolution was now on [sic] the air in every country in the Middle East. Bahrain and Iraq with substantial Shiite majorities were particularly threatened by the ideas from across the border, which at any time could trigger a Shiite insurrection'. ${ }^{14}$ In other instances, Bahraini support for the revolution is unsubstantiated and vague, with little specification given about the extent of its appeal. For example, Jeremy Jones and Nichoas Ridout note that the 'Bahrain Shi' a had demonstrated in support of the Iranian Revolution in February 1979 and again in August'. ${ }^{15}$ Mehran Kamrava singles out the Iranian Revolution as a creator of 'chaos': 'The rulers of these countries see these uprisings as their most serious crises since the Iranian revolution threw the region into chaos in the early 1980s'. 16 David Commins notes in his history of the Gulf States that, 'quite simply, the Iranian Revolution threatened the political survival of the Gulf States' ${ }^{17}$ Ma'oz suggests that the Islamic Revolution 'provided Bahrain's Shi'i majority with a model of a state that would emancipate them and represent their identity'. ${ }^{18}$ Other scholars, such as Hasan al Hasan, have explored in depth the extent to which the IFLB were backed by Iran, or Iranian elements, thereby reifying this discourse while simultaneously highlighting that the Bahraini government have failed to substantiate the evidence ${ }^{19}$. 
This narrative is also reflected in numerous policy documents or reports by various Think Tanks. In a 2016 report for the Atlantic Council, Bilal Saab states that the Iranian Revolution was the catalyst for the creation of communal tensions: ' Bahrainis are repulsed by the thought and reject the notion of sectarian division in the country, citing decades of communal peace and coexistence (until the 1979 Islamic Revolution in Iran)'. International Crisis Group, reporting an interview with the Bahraini activist Ibrahim Sharif, argued that 'prior to 1979 the government did not pursue a specifically sectarian agenda, since it viewed the most serious threat as emanating from leftist organisations'. ${ }^{20}$ Among these analyses there tends to be, with varying levels of nuance, assertion, allusion, or assumption, that the Islamic Revolution either galvanized or inspired the Bahraini Shi'a, or formed the key basis for their ethnoreligious and sectarian persecution. In various iterations, numerous scholars and commentators have contributed to the emergence of a totalising narrative, arguing that the revolution altered threat perceptions, injected religion into politics, or deeply transformed Bahraini society. With few exceptions ${ }^{21}$, the transnational threat of the Shi'a and the Iranian Revolution as a turning point has become a metanarrative in discussions of Bahrain, forming an uncritically embraced normative trope that can serve to justify suspicion towards the country's Shi'a. From discussion of the regime's threat perception to an assumed belief in Shi'a unity, discourses have approached the Revolution as totalising in its impact, both from below and above. While the long-standing persecution of the Shi'a in Bahrain is generally acknowledged by most academics, the emphasis on the Iranian Revolution as a key moment in Bahrain's history is a somewhat dissonant element that sits incongruously within broader analyses.

\section{Revisiting the Revolution}

In many cases, it has become a truism that the unrest and demonstrations that occurred in Bahrain in 1979 and 1980 were all related to the Iranian Uprising. However, claims of causality between the Iranian Revolution and unrest in Bahrain are often contradictory, unsubstantiated or lack nuance. Gregory Gause noted that after the Iranian Revolution, 'Unrest occurred in Bahrain, the only Gulf shaykhdom with a Shi'i 
majority, in August 1979... 22 Imad Salamey and Zanoubia Othman wrote, 'the appeal of Khomeini's revolution mustered popular support among the Shi'a in Lebanon, Iraq, Kuwait, Bahrain..... ${ }^{23}$ It is notable that the affect in Bahrain did not resemble, for example, the Qatif Uprising in Saudi Arabia. ${ }^{24}$ There is some discord here though. As Laurence Louer notes, Bahrain is an exception in the Gulf, mostly because the Shi'a are mainly concerned with political participation and democratization. ${ }^{25}$ Similarly, Amelia Ilsa Schumacher notes that Iranian attempts to send emissaries to Bahrain following the revolution were largely ineffective due to the fact that there was no unifying 'Shi'a brotherhood' in Bahrain, and that reasons Shi'a dissatisfaction with the Al Khalifa government did not translate into a willingness to welcome or support the Revolution. ${ }^{26}$

With this incongruity in mind, recently released historical documents show that the impact of the Iranian Revolution was, at best, ambivalent. Harold Walker, the UK Ambassador to Bahrain, who was stationed in Bahrain during 1979 and frequently in touch with the security services, noted that, 'Since the Iran/Iraq conflict began, there have, as you know, been virtually no visible signs of support among the Bahraini Shi a for the Imam Khomeini'. ${ }^{27}$ As such, in 1980, the Bahraini authorities predicted a peaceful Ashura commemoration. Walker also wrote in November 1980: 'no necessary reason why the Ashura celebrations should lead to political disturbances any more than they have over the last decade'. The relative quiet actually surprised Walker, prompting him to bring it up with the then ruler, Shaykh Isa bin Salman Al Khalifa. In October 1980, Harold Walker explicitly discussed why 'the Shi'i villages had done no protesting or demonstrating in favour of Khomeini'. Shaykh's Isa's response was that the 'thorn was broken', and that knowledge was spreading in Bahrain that life in Iran was not a 'bed of roses' ${ }^{28}$ It is perhaps unusual then that Harold Walker, the UK Ambassador to Bahrain during the Revolution noted in a 2011 blog post for the Conservative Middle East Council: 'Since the 1979 Islamic revolution, the impact of Iran has been the single most important factor in fragmenting Bahraini society and injecting religion into opposition politics '.29

Of course it is important to note that the Iranian Revolution had important resonance in Bahrain ${ }^{30}$, yet this impact was far from universal, and certainly more nuanced than a general assertion of support for revolutionary Iran. Sophia Pandya argues that Bahriani women revealed how many sought inspiration from new, 
contemporary Iranian clerics, (although this still does equate to demanding a revolution). ${ }^{31}$. Walker noted that the revolution had given the Shia a 'psychological boost', and encouraged some to press a list for twelve demands, that included asking for some form of Islamic governance, to saying music should not be taught in schools. The government's response was to allow the Shi 'a to 'blow off steam', and a number of demonstrations were held in August 1979. ${ }^{32}$ Ultimately though, these demands were not dissimilar from those advocated by the Shia bloc during Bahrain's short-lived National Assembly from 1973-75.

Yet there is also evidence to suggest it was the Bahraini government's response to demonstrations relating to the Iran/Iraq war that had more immediate consequences in terms of unrest in Bahrain around the time of the Iranian Revolution. One such demonstration occurred on 24 April 1980, at a protest of Iraq's execution of the cleric Mohammed Baqr al-Sadir. After securing permission from the authorities, a few thousand people marched in protest at the killing. Sixty-four people were arrested, including Jamal Ali Muhsin Al Ali, a young Bahraini, who authorities accused of attacking and wounding two Bahraini Army Intelligence officers in the suq ${ }^{33}$. Ali was tortured to death in police custody on May $10^{\text {th }} 1980$ and his 'well photographed wounds inflicted by the Bahraini Police' made him, according to one British official, the 'first Bahraini Shi 'a martyr'. ${ }^{34}$ This police violence was exploited by Hadi al-Mudarrasi, a cleric living in exile in Iran and who was argued to be the key link behind Iranian-led insurrection in Bahrain. More demonstrations occurred on the 18th and 19th June, when al-Mudarrasi called on Bahrainis to mark Arba 'in, the forty-day anniversary of Jamal's death. It is perhaps unsurprising that the well photographed torture marks of Jamal should elicit an angry public response, especially considering that he was, according to FCO documents, innocent. ${ }^{35}$ Even so, according to FCO documents, while 1,000 gathered, it was peaceful apart from tyre burning. Later on, the torture and killing of Mohammad Hassan Madan in a Bahraini prison on February 14 1981, resulted in three days of protests, which resulted in another death, this time of a young boy called Adil Khoki. ${ }^{36}$ Indeed, it was only after 1975 that death by torture in Bahrain's prisons, which had not been reported between the 1920s and the 1970s, became more prevalent. Between 1976 and 1986, eight people died in police custody, and Amnesty International and the British Parliamentary Human Rights Group reported that at least six of those 
were believed to be because of torture. ${ }^{37}$ In this regard, the rise in police brutality, the reasons for which shall be discussed later, was also an important factor in local demonstrations, yet these are rarely elaborated upon.

\section{Transnational narratives versus longstanding discrimination}

In addition to exaggerating the impact of the Revolution's appeal, the salience of the Iranian Revolution as a turning-point discourse is problematic as it positions the Shi'a as a security threat, implying that they are somehow agents of their own persecution. This totalizing narrative reflects the contemporary politicisation of Shia/Sunni sectarian relations, and detracts the focus from a fundamentally oppressive political system that has been documented since, at least, the Al Khalifa conquest of the Bahrain islands. Because of the often ill-defined nature of the term 'sectarianism', there has been a tendency to parse it off from other explanatory variables, resulting in a sui generis approach that ignores fundamental aspects of intersecting discrimination, culture and social conditions ${ }^{38}$. McVeigh argues that sectarianism has been undertheorised and actually constitutes a form of racism. ${ }^{39}$ Fanar Haddad echoes this sentiment, noting that academic theorising of race relations is fare more nuanced than the often crude application of 'sectarianism'. ${ }^{4041}$ In the case of Bahrain, ethno-religious discrimination of a former serf/slave population, one in which specific members of the Shi' $i$ community can still also achieve positions of high office, has taken on the rigidity of institutional discrimination. It is important to question to what extent this ethnoreligious discrimination and tribal-familial exclusivity among the ruling elite informs state violence, and how long it has lasted, in order to better counter the 'turning-point' discourse. Indeed, the historical record suggests that it was in times of increasing persecution in Bahrain that inhabitants sought protection, rather than passively adopting exogenous beliefs based on ideology alone. In 1921, Major Clive Daly, the British Political Agent in Bahrain, stated that he was often asked, 'Why do you not remove British protection then we would at least have the redress usually resorted to by Arabs. We should appeal to another Arab ruler to take over our country and treat us better'. ${ }^{42}$ 
major variables as emanating from external sources, can often be rooted in the political ideology of a multitude of prisms, from neo-imperialism itself, to postcolonial discourses and Arab Nationalism. The most obvious example is the aforementioned transatlantic antipathy towards Iran, a result of the humiliation faced by Britain and the US following the ejecting of the Anglo-Persian Oil Company and the overthrow of the Shah respectively. Yet part of the problem in studying Bahrain, perhaps, also lies in the application of what has become a Eurocentric phenomenon of modernity to analysisone, in which the creation of the state and its institutions through colonialism is somehow the subject of focus, and one that can result in total disjuncture between a previous era and the 'modern'. ${ }^{43}$ In this analysis, concepts such as sectarianism somehow become a neatly packaged and temporally limited product of modernity. For example, it is contentious to argue that "the 'vertical segmentation' in Bahraini politics was not an age-old form of political mobilization, but a modernist one whose roots were sculpted during the period of British divided and contested rule in 1900-1923, and in the colonial ethnosectarian gaze that accompanied it". ${ }^{44}$ This argument places the roots of sectarian tensions at the British administration, reflecting underlying tones of Arab Nationalism, whose central tenets rallied against imperialism. Certainly, postOrientalist analysis and post-colonial critique have used it to buttress the anti-imperial tenets of Arab Nationalism which sought to define sectarian antipathy not only as deviant, but also as a colonial construct ${ }^{45}$. While there is clearly truth in this, it does not make it wholly accurate, and such arguments run the risk of creating the illusion of a pre-imperial utopia.

Despite the analytical richness of such writings, it leads to arguments that again, seek to explain phenomena such as sectarian tensions as being primarily or solely the work of external agency, beginning at a specific point. This results in the problem of potentially attributing subaltern victimhood to those who may be active agents in a discriminatory apparatus. Such arguments run the risk of ignoring the colonising agency or prejudices of local actors, or undermining the significance of local social, political or cultural contexts that are capable themselves of mobilization, discrimination, and prejudice. In recent years this has been abetted, for example, by King Abdullah of Jordan, whose discourse of a rising Shi'i Crescent has become a 'self-'fulfilling prophecy', reflecting not necessarily the threat by 'the Shi'a', but that the 'Arab world 
has identified the region's Shi'i communities as threats to their authority'. ${ }^{46}$ While we should not be dismissive of any of these variables, there is a danger in Bahrain that they feed into a simplified binary of contemporary identity politics, where Shia/Sunni tensions are structured according to Western security strategy, and are therefore 'blamed' specifically on Shi'i 'victories and Persian/Iranian aggrandizement. For this reason, any analysis must not preclude consideration of the underlying conditions, behaviours, individuals, beliefs, and institutions, that existed beforehand by overstating the disruptive power of the colonial state. Like the British-led reforms of the 1920s, the Iranian revolution and the Iraq Invasion of 2003 have been recently argued to be a turning point in the emergence of sectarian political mobilization in Bahrain, reflecting not only a simplified notion of transnational identity politics, but also an objectification of the Shi'i population as a passive subject, dependent mostly on the whim of ideological pulls, administrative reform and colonial intervention. Just as such sectarian approaches run the risk of essentialising Shi'a as passive automatons, so too does it paint Sunnis as unyielding and subject to an instinctive fear of the prospect of a Shi ${ }^{6} \mathrm{a}$ crescent. $^{47}$

\section{The persecution of the Bahārna and the Shi 'a}

Rather than seeing a turning-point narrative as the key causal agent, it is important to examine long-standing processes of persecution in order to get a sense of how injustice has been key in provoking demands for political change. In 1984, Ilsa Amelia Schumacher's ethnography conceptualised a 'traditional Sunni' perspective of the

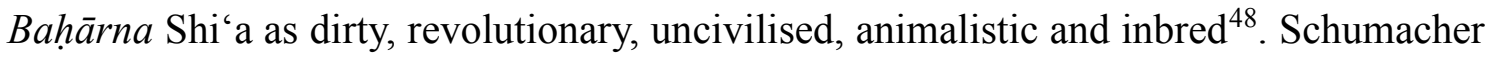
goes as far as to argue that even certain historic 'privileges', such as the government's permission of Ashura rituals, are a means of maintaining a Sunni Shi'a division by 'morally demolishing' the Shi'a in Sunni eyes. In this, the Bahraini represents the urban, civilised Sunni, while the Bahārna is the Shi' $\mathrm{i}$ antithesis. A similar discourse analysis I conducted in 2010 suggested findings similar to Schumacher's, noting how in the contemporary regional context, Shi'a were often derided as 'being terrorists, uneducated, apostate, traitorous, sexually promiscuous, untrustworthy, violent, deviant, 
backwards, Iranian, Jewish or Rafadites'. ${ }^{49}$ Schumacher's study, which took place during and immediately after the Iranian Revolution, reflects not simply a postRevolutionary reaction against the Shi'a. On the contrary, the attitudes mentioned appear to have deeper roots. In fact, sectarian tensions had not only been evident throughout the $20^{\text {th }}$ century, but Shi'a had long been viewed with suspicion prior to the 1979 Revolution.

While we must be wary of clear-cut ruptures, periodisation, causal shifts, and even path dependencies, the arrival of the Al Khalifa in the 1780s, and whatever their 'gaze' (to use the post-colonial term) might be, was key in altering the existing modes of production vis-à-vis the indigenous Bahārna and ruling family. The feudal system established by the Al Khalifa was one of economic exploitation that frequently resulted in violence. Indeed, this tribal overrule was differentiated from Bahrain's many previous occupiers by the appropriation of 'every resource'. ${ }^{50}$ Crucially, as Jiwon Choi has convincingly argued ${ }^{51}$, this was a settler-colonial relationship, one in which the Bahârna experienced the 'confiscation' of lands ${ }^{52}$ and other forms of discrimination. Certainly, at this time, it was not the ideological currents from outside that determined the attitudes of the Bahärna to the government, but rather their treatment by the internal powers, which also occurred along sectarian lines. For example, in court, two Shi'i witnesses equalled one Sunni witness.[rp1 $]^{53}$ The Shi 'a also faced multiple taxes, which included a Muharram tax and a Shi'a tax. In the 1850s, the British often noted but ignored this persecution. Captain Taylor observed of the Bahārna under the Al Khalifa that, 'The aboriginal inhabitants of Bahrein, now subjected to a foreign power, suffer from the tyranny of their masters more keenly than language can express'. ${ }^{54}$ There were frequent reports of collective punishment in the early 1900s. Sometimes whole villages were burnt to the ground, or ransacked by members of the Al Khalifa family or their tribal allies, such as the Dawasir. These raids often resulted in numerous deaths. Certain members of the ruling family, such as Abdullah bin Isa Al Khalifa, the Ruler's brother, were singled out by the Bahärna to the Political Agent for engaging in numerous acts of rape, extortion and kidnap. ${ }^{55}$ In 1921 a petition by a large deputation of Bahraini subjects noted that the 'Shi' ah [sic] community [was] in a state of great humiliation and subject to public massacre' ${ }^{56}$ by the ruling family and their tribal allies. It was this brutality and oppression that frequently mobilised the Bahārna. For example, in 1922, 
around 1500 Bahārna camped around the British agency flagstaff for protection over several evenings. According to Michael Herb, it was the abuses endemic in the feudal system that 'laid the foundations for the sectarian divide that dominates Bahraini politics today' 57

As part of the British reforms, numerous changes were made to limit the 'oppression' of Bahārna subjects. This fundamentally altered the relationship of the British with both the Al Khalifa and the Bahärna. In exchange for compliance with the law, and to prevent tribes from attacking the Bahārna, and European traders, the Britishappointed Shaykh Hamad bin Isa Al Khalifa to hold the purse strings, and cut off members of the family who disobeyed him. New courts were also created, in part to prevent a 'grave injustice' being done to Shi'a in Sunni courts. The British also deported the Dawasir Tribe to the Arabian mainland, as they were often implicated in the oppression and overawing of the Bahärna. The reforms, however, represented an awkward mixture of British reluctance to intervene too much in internal governance, but also a vested interest in facilitating their own capital-orientated and empire-building priorities. The impact of reforms was neither absolute nor immediate, with members of the ruling family threatening collective punishment to Bahärna villages as late as the 1930s. Yet it is important not to portray Al Khalifa acquiescence or colonial overrule as totalising. Even after the reforms, many Bahārna were still paying taxes at the whim of certain members of the ruling family. In a communique sent in 1929, the British administrator Prior noted that Hamad, the then ruler, 'despised' the Bahārna ${ }^{58}$, while in 1932 Belgrave stated that ruling family were flexible regarding land reform, 'except that the Baḥārna should acquire any rights to land'59. The general ruling family's continued hostility to the Bahārna was also embodied in the denigration of the Shia for those members of the family seeking to break the sectarian divide. When a member of $\mathrm{Al}$ Khalifa family 'converted' to Shi'a Islam, members of the Al Khfalia family reportedly took to the markets to ridicule him, an act that resulted in increased communal tensions.

Although the wide scale abuses faced by the Bahārna in the 1800s and early 1900s were not replicated[rp2] as they had been, communal strife enflamed periodically. The British reluctance and even inability to tackle this discrimination was evident as late as the $1950 \mathrm{~s}$, when they were still attempting to cover up tribal oppression that provoked communal tensions. Tensions erupted again in 1953-54, when a 'handful of 
Sunni agitators, including at least one member of the Al Khalifa ruling family, insulted the annual Ashura procession that the Shi' a organize to commemorate the martyrdom of Imam Hussein. Other incidents followed: a Sunni crowd attacked a Bahraini village and rioting between Sunni and Bahraini workers occurred in BAPCO' ${ }^{60}$ According to Charles Belgrave, in 1954, the son of the ruler was driving around with armed retainers attacking Bahāarna villagers. This son, Mohammad bin Salman Al Khalifa, later became chief of Bahrain Police and Public Security during the 1960s (itself an alarming development). Violence, which resulted in numerous deaths in 1954, 1956, and 1965, was often, according to Belgrave, exacerbated by institutional prejudice. This was epitomised in 1953, when Belgrave noted, 'one of the policemen referred to the Shi 'a as "the enemy" \& that is the way they regard it'. ${ }^{61}$ Yet Belgrave's observation masked the fact that the recruitment into the police was largely governed by the British, and in part it was their own colonial conceptions of race and character that prevented them from, for example, recruiting Bahārna. ${ }^{62}$ This maintenance of communal tensions was also aggravated for the sake of political expedience. For example, when the Committee of National Union (CNU) [rp3]was mobilising Bahrainis to support various reforms, the British actively sought to exploit political divisions by reminding the Shi' a community of how the British had defended their interests, and that it would not be in their interests to join the agitation.

Leading up to Bahrain's Independence in 1971, tensions emerged in particular over the treatment of both Bahraini Shi'a and Iranians living in Bahrain, reflecting underlying currents of division. In the 1960s, Iranian claims to Bahrain contributed to tensions by some against the Bahraini Iranian community. A demonstration broke out in 1968 in which a group of around two thousand people denounced the Iranian claim. Some scuffles reportedly broke out between Iranians and Arabs. In a small counterprotest, a group of Iranians held up pictures of the Shah. It was for this reason that the Bahraini authorities began deporting Iranians living in Bahrain. The British administration, already preparing for their own departure, advised the ruling family against deporting Iranians, as they had 'no intention of persecuting the Iranian community'. Yet the process continued. All foreigners were summoned to courts to have their residency visas renewed. Unsurprisingly, many Iranians refused to even show up. The British claimed that Jordanian judges working in Bahrain, in a wish to demonstrate 
their Arabness, did not renew Iranian permits.

Sectarian divisions were once again evident as the Bahraini government prepared for the departure of their British protectors, by creating the National Guard in 1968 (which later became the Bahrain Defence Force [BDF]). In addition to the aforementioned government hostility towards Iranians in Bahrain, discussions about the makeup of the armed forces took sectarian composition into consideration. Anthony Parsons, the British Political Agent in Bahrain between 1965 and 1969, noted that the recruitment of the Shi'a in the BDF was to be capped at $25 \%{ }^{63}$ This perhaps goes against Louer's notion that it was after the Iranian Revolution that 'the threat perception of the regime underwent a deep transformation', ${ }^{64}$ adding that: 'With the all-out use of the Shi'a religious identity for protesting against the regime, the Bahraini rulers began to embrace a sectarian definition of concepts of loyalty and disloyalty, being tempted to see any Shi'a as a potential threat'. ${ }^{65}$ While Louer examines and notes the rise of Shi'a movements in Bahrain in the late $1960 \mathrm{~s}$ and $70 \mathrm{~s}^{66}$, the idea that regime's threat perception deeply transforming as a result of the Iranian Revolution is perhaps an overstatement. Concepts of loyalty and disloyalty had been extant long before the Iranian Revolution.

\section{Resurgent modalities of repression and their causes: From independence to the Iranian Revolution}

Given the apparent embedding of the Al Khalifa legacy of conquest and the relatively short time since the reforms of the 1920s, there is little substantial evidence to suggest that prejudicial attitudes have not died out in the contemporary period, or failed to inform policy. To a certain extent, elements of contentious politics in Bahrain can partly be ascribed to a bifurcation of control strategies formulated by a dialectic between two powers with immediate hegemony in the geographic locale: Britain and the ruling tribal Al Khalifa family. This dialectic shifted with increasing British encroachment in Bahrain's internal affairs, and impacted upon the modality of repression. The resultant compromise, or 'friendship' as the British and Bahraini governments call it, was the 
ossification of Al Khalifa rule through British protection and legitimization, the legal formalisation (in a European sense) of Al Khalifa settler colonialism, but also the temporary hiatus of a specific modality of repression, which had hitherto been their unlimited feudal rights over the local Bahāanna population. ${ }^{67}$ Sectarian tensions did not disappear following the reforms of the 1920s, but its manifestation altered significantly with the disruption of feudal rule, becoming perhaps less visible, less arbitrary, and less overly acceptable as a means of economic subjugation and control. However, the fundamental power base did not change significantly. While repression occurred before and after independence, all repressions are not equal. Just as Davenport argues that differently types of authoritarian regimes repress differently, modalities of repression change depending on a number of things, including; governance, threat, external factors, ideologies of elites, etc. ${ }^{68}$ Given the shift in modalities of repression during the British protection of the Al Khalifa, the British departure in 1971 provides an interesting juncture for the analysis of post-Independence contentious politics. Similarly, the change in control of the security forces is an important object of examination, for they are an important body whose capacity for violence has long defined communal differences. ${ }^{69}$ In this regard, rather than emphasising the Iranian revolution as the main driver in changes in the nature of the treatment [rp4]of political opposition, one must also consider the changing power structures and institutions as causal agents in this change.

\section{Calling the shots: The repressive apparatus}

While one of the key British reforms of the 1920s had been the creation of a police force and the regulation of violence, even prior to Independence, the ruling family increasingly defined much of the security policy. This significantly altered notions of threat perception and how to deal with dissent. After Independence, cables from both the Foreign Office and US State Department acknowledged the declining influence of the British head of police, Jim Bell, and the British head of special Branch, Ian Henderson. In the early $1970 \mathrm{~s},{ }^{70}$ both were 'excluded from various private lines of command influence'. ${ }^{71}$ Furthermore, Henderson was 'no longer allowed to detain or interrogate' detainees as he saw fit. ${ }^{72}$ In 1973, it was reported that the Prime Minister had the last word on matters of internal security and basic foreign policy ${ }^{13}$ and kept police and special branch 'closely under his own control'. ${ }^{74}$ By 1975 the Prime Minister 
reportedly had ' his own way on security matters which were his sole responsibility'. ${ }^{75}$ If true, this reflected a shift in power at the Ministry of Interior -towards the Prime Minister, Shaykh Khalifa bin Salman Al Khalifa, and a merchant elite, who Harold Walker said included the al-Moyad and al-Zayani families. This hard-line relationship was highlighted as early as 1974, with the British reporting that 'the government and the merchant class thought it was time to take a firm hand ${ }^{176}$ against any unrest. It was in this context that general treatment of the opposition changed. Under the Prime Minister's oversight the Popular Front for the Liberation of Oman and the Arabian Gulf (PFLOAG) was dismantled. ${ }^{77}$ In 1974 the Prime Minister almost doubled the security budget as insurance against potential legalisation of non-political trade unions, again, reflecting a broader shift in the nature of threat perception and hard-line attitudes towards organized opposition. ${ }^{78}$ Despite the presence of the US base, the postIndependence protection vacuum was filled by the ever-increasing influence of Saudi Arabian authoritarianism, which one official described as 'too Islamic' and 'too close for comfort ${ }^{79}$. As early as 1972, the British noted that in many ways, the Saudis were more of a worry than Iran, due to their influence and conservatism. ${ }^{80}$ Prior to Independence, the prospect of having Bedouin in the security forces was shot down by the British administration, who were advising on the creation of the new army. Yet by 1982, the recruitment of 300 'kindred tribesmen' from Saudi into the security forces raised issues of whether they would impact upon institutional prejudice ${ }^{81}$. It appeared Saudi's influence was especially evident in the Prime Minister, who was reportedly unwilling to defy King Faisal ${ }^{82}$. So, in addition to the internal reversion back to Al Khalifa dominance in internal security policy, the previously dominant British- Al Khalifa dialectic that informed approaches to security was now being usurped to some extent by a 'conservative Sa'udi-Al Khalifa nexus' ${ }^{83}$. Yet while much discussion has focused on Iranian-subversion as a catalyst for changing threat perceptions, or Shi'a susceptibility to ideological control, little is made of Bahrain's actual alliance with Saudi Arabia.

Independence, and the changing dialectic of external overrule, reorientated the modalities of repression against the opposition in general[rp5]. This was especially evident in the treatment of the Shi'a and Bahārna. For example, while the government had predicted a peaceful Ashura in 1980, the Prime Minister said that firm action would 
have to be taken once Ashura was out of the way. When asked why, the Prime Minister reportedly stated to Ian Henderson that he wished to demonstrate that the 'Bahrain Government were true Arabs ${ }^{84}$. The meaning of this comment is not clear, yet Geoffrey Arthur, after meeting with members of the Al Khalifa, stated that the Arab/Persian rivalry was perhaps more significant in formulating opinion of the Shi'a in Bahrain, noting that the 'Bahraini ruling family were far less worried by the direct influence which Khomeini and the Iranian evolution might have on the Shi'i majority in Bahrain than by the risk of the installation of a Shi'i government in Baghdad'. Despite the peaceful passing of 'Ashura, the Prime Minister took this 'firm action', ordering the

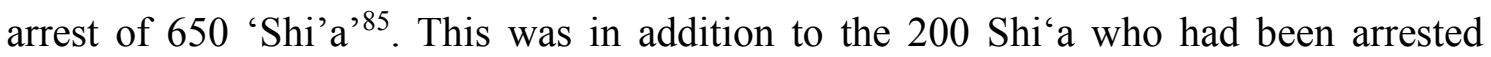
beforehand. ${ }^{86}$ The fact that Ashura had passed peacefully reportedly 'encouraged' the Prime Minister to order widespread arrest of Shi'a. While Ian Henderson has been accused of personally engaging in torture by some Bahrainis, communication with the British Embassy in Bahrain show that he actually disagreed on a policy level with the decision to order this crackdown, advising 'the Bahrainis strongly against this course of action, saying that it was likely to lead to more Shi' $i$ 'martyrs' and would probably have the opposite effect from that desired' ${ }^{87}$ Henderson complained about a similar issue in 1982, objecting to the fact that the Prime Minister and King were illegally deporting Bahraini nationals to Iran, ${ }^{88}$ which had also happened in the late sixties. Specifically, Henderson feared that this would exacerbate the security situation in Bahrain by furnishing the ranks of subversives training abroad. While these fears resembled those iterated by British officials in 1968, the deportations in 1982 were actually of Bahrainis and not Iranians living in Bahrain, reflecting not simply a resurgence of sectarian animosity, but, in line with the Prime Minister's aforementioned comments, an Arabisation of Gulfness (as opposed to a Gulfisation of Arabness).

It is interesting, and rare, to have such an opportunity to compare different responses to a perceived security threat. The Prime Minister's decision, likely taken with advice from the new conservative core, were based on an entirely different approach to repression, one that is unlikely to be devoid of specific prejudices, interest protection, or the trappings of the 'legacy of conquest'. The disagreement of the Prime Minister with Ian Henderson symbolises a friction not necessarily in the objective threat posed by Iran, put perhaps in the ideological constraints on the modalities of 
repression', ${ }^{89}$ which influence the attitude towards what repressive action to take, itself a notoriously underexplored aspect of repression literature. Such a question should also raise interesting questions about the nature of the 'authoritarian reflex', loosely defined 'by a relative lack of inhibition or restraint on the use of power' ${ }^{90}$. It can hardly be said to be black and white, but one of degree, where 'lack of inhibition' in the use of power is highly dependent on the beliefs of those responsible for its deployment, as well as other contextual considerations. It would be difficult to argue that the increasing brutality of the police, which had its inception long before the Iranian Revolution, was not contributing to rising tensions, and indicative of not simply a shifting 'threat perception', but a differing authoritarian reflex, and a reciprocity between repression and dissent. Similarly, while Gause argues that countries like Bahrain had successfully staved off revolution by modernising, it would seem that a Shi'a insurrection did not occur despite repression, and that in many cases, policies were undertaken that could actually exacerbate hostility to the regime. Indeed, while the Prime Minister's actions occurred in the aftermath of the Revolution, they were not undertaken on the grounds that those arrested or deported were posing a clear security threat. They were taken with the warning that they would exacerbate any hostility towards the regime.

\section{Dissolving the National Assembly}

In addition to the role played by the security services, Bahrain's brief democratic experiment between 1973 and 1975 had also contributed to strengthening a unified opposition, reflecting a resurgence of what might be termed deliberately divisive politics ${ }^{91}$. Whereas the government had hoped that the so-called 'people's bloc'92 and 'religious bloc' would always be at loggerheads, their joint opposition to the

government-proposed Security Law created an alliance. ${ }^{93}$ This unity had alarmed the regime and contributed to them dissolving parliament, for fear that legal unity of opposition could transcend the oppositional fragmentation that the Al Khalifa regime had used to keep the opposition divided and weak. For this reason, the government tried to drive a wedge between the leftists and religious elements, isolating them. As such, the period following 1975 was important, as it marked a 'reconfiguration of the Bahraini opposition landscape'. ${ }^{94}$ Only a year after the creation of parliament, the British official Robert Tesh noted that the 'rulers are deliberately encouraging the Right (particularly 
the Religious group) to react against the Left ${ }^{195}$. One minister insisted that the left were being successfully smeared as communists and were becoming generally unpopular. As occurred with the Shi'a being painted as an exogenous fifth column, the regime also 'deliberately exaggerated' the extent to which leftist groups were taking orders from outside the country. ${ }^{96}$ Tesh noted that a "'divide and rule" policy does, however, have its dangers and creates the possibility of violence'. ${ }^{97}$

The rift between the left and conservative elements was further driven home in 1976 with the high profile murder of Shaykh 'Abd Allah al-Madani, a Shi'a religious scholar and editor of the local newspaper Al-Mawaqif. Maintained by many Bahrainis as a government conspiracy, his murder resulted in a further shift in the modalities of repression, and a different approach to interrogation and torture. ${ }^{98}$ The murder, after which there was a summary political trial, was used by the Bahraini authorities to justify a crackdown on leftist political groups in Bahrain, and resulted in a policy that had previously prevented targets of subversion from being arrested, and therefore tortured. As Given[rp6] noted, 'the 'murder removed the restriction on the interrogation of Popular Front suspects, and enabled the police to acquire a clearer picture than before of its ramifications and activities'. ${ }^{99}$ Prior to this, 'the absence of interrogation of suspects meant that the police received only the amount of intelligence which their sources in the NLF cared to give them'. ${ }^{100}$ The policy seemed to immediately follow the death of two Bahrainis, Muhammad Ghulum Busheri and Sa'id al-'Uwaynati, who were killed under torture following their arrest. Although the trial was highly politicised, and the evidence shaky, the ruling family used it as an opportunity to concentrate in their hands both politically sensitive posts and those relating to social affairs. ${ }^{101}$ Saudi pressure was strongly evident in the trial, and they, along with the Prime Minister, were pushing strongly for death penalties, which were successfully carried out in $1977^{102}$. With the wholescale crackdown on the leftist movement, and their perceived role as being involved in anti- Shi'a attacks, it was much easier for an Islamist opposition to appear dominant. In this regard, the threat of popular politics in infringing on increasingly limited Al Khalifa resources prompted an aggressive strategy of stonewalling participatory politics. While the suspension of parliament and Ayatollah Ruhollah Khomeini's criticism of Gulf rulers may have been amplified by the suspensions of parliament ${ }^{103}$, the revolution undoubtedly resonated more broadly due to dashed hopes, 
growing corruption, torture, police repression, and a firm line towards political opposition. Yet this talk of amplification|[rp7]negates the issue of whether or not elements of Ruling Family/Saudi conservatism played out in terms of the [rp8]Bahraini authorities' response to both political opposition and the country's Shi'a population. Indeed, it would seem that the shift in modalities of repression, especially in the treatment of the Shi'a, do not simply reflect a rational security strategy. Such a strategy would fit in with Fuad Khuri's argument that the regime had always preferred Islamist opposition as it was easier for them to control traditional terms. ${ }^{104}$ Even without parliament, the fear that a cross-identity opposition could transcend organizational fragmentation to unite a previously disparate opposition against the tribal governance of the Al Khalifa was very real. Certainly, the destruction of a once active leftist community would have made more visible the religious opposition. This certainly casts doubt on Louay Bahry's argument that the Iranian Revolution was the cause for the decline of alternative opposition, as if its ubiquitous influence was entirely attributable to its own resonance with the country's Shi'a. Bahry notes that, 'Until the 1979 Islamic revolution in Iran, this secular opposition led the drive for political reforms in Bahrain, but the success of the Iranian revolution introduced an entirely new concept into opposition dynamics in Bahrain--the use of religious symbols as a political tool' ${ }^{105}$. It would be logically problematic to argue that the leftist opposition were simply usurped by the popularity of Iranian-trained clerics who only after the Revolution used the pulpit to put forward progressive issues such as constitutional reform and human rights ${ }^{106}$.

\section{Actual and anticipated economic fallout.}

In addition to shifting changes in the authority structures in Bahrain, and a less tolerant approach towards opposition, economic factors were among those contributing to unrest in the country. While Gause argues that the failure of the Iranian Revolution to trigger an uprising in Bahrain rested on the capacity of the state to provide services for citizens may be somewhat economically deterministic, Frederic Wherey adds that on the eve of the Revolution across the Gulf, the 'Shi' a were faced with a combustible blend of rising expectations, poor living conditions, and limited avenues for political participation'. ${ }^{107}$ Add to this rising corruption and cronyism, which was actually becoming an increasingly large problem. The wealth that accrued to the [rp9]ruling family through oil 
royalties was now being used to exploit the real estate market, increasing the gap between haves and have-nots ${ }^{108}$ while underscoring disgruntlement, corruption and wealth appropriation. It is also possible that the 1971 limitation of oil revenue payments ${ }^{109}$ to the Amir led to an increasing demand for members of the Al Khalifa to secure other means of income now that the civil list had diminished. This too could explain why the ruling family were reportedly 'squeezing out established merchants' and moving into other areas of business, ${ }^{110}$ while also 'closing ranks'. ${ }^{111}$ Naturally this affected the poorest section of society, the Bahāarna Shi'a, who had largely been, as mentioned previously, deliberately excluded from the privilege of ownership and inherited land rights. The Bahāarna suffered most from rising inequality, a fact that Fuccaro notes has shaped the urban topography of Bahrain, creating satellite villages in which marginality and militancy flourished ${ }^{112}$. Yet while Fuccaro argues that this militancy gathered momentum after the Iranian Revolution, Schumacher's ethnography in the 1980s highlights that while many Bahrainis supported radical political change, it was not because 'Khumayni [sic] was their avowed spiritual leader, but because they see the Al Khalifa as unfairly siphoning off the country's wealth for personal advantage'. ${ }^{113}$ It is this unfairness, Lawson also argues, that provided the impetus for the 1990s Intifada ${ }^{114}$. The economic stagnation that began to set in during the latter half of the 1980s also led to fear that Bahrain's Shi 'a, who represented the country's working class, would become increasingly restive. This growing Baḥārna-working class threat intersected, and was thus perceived as a potential time bomb, regardless of the Iranian Revolution.

\section{Conclusion}

Numerous scholars have argued that the Iranian Revolution was a major distal shift in Bahrain's politics, especially with regards to the role of religion in society. This emphasis has detracted from other explanations that suggest more complex variables for the treatment of the population. By revisiting both this period and the decades preceding the Revolution, as well as by looking beyond economic determinism, it becomes clear that the[rp10] persecution of the Shi'a in the 1970s and 1980s was the result of the 
convergence of numerous factors that had been incubated over several decades of British overrule, and catalysed by Bahrain's Independence in 1971. Of course, these variables include the Iranian Revolution to some extent, yet this emphasis perhaps obscures other important factors in the mix. Indeed, shifts in the power-dialectic, longterm marginalisation of the Shi'a, the creation of a Shi 'a working class, economic fears, the rising influence of Saudi, the increase in operational control by the ruling family, and the less constrained articulation of Al Khalifa ethnocentrism all seem to underline an explanation for increased repression of the Shi'a and opposition in general[rp11]. The focus on the Islamic Revolution seems to have produced an agenda-setting fulcrum in the historiography of Bahrain, one in which current contextualisations of the Shi'a threat obtain purchase, leverage, and credibility. This is dangerous as it may, in some policy circles, evoke sympathy for a discriminatory political system on the basis that the Government of Bahrain are merely countering an exogenous threat. It would be more accurate, in my opinion, to argue that since independence there has been a reassertion of the Al Khalifa legacy of conquest, wherein the country's Shi'a, and in particular the Bahārna population, have been treated with increasing contempt. Indeed, it was independence that caused a re-assertion of Al Khalifa dominance in matters of internal security, which in turn impacted upon how the security forces dealt with any perceived threat, whether leftist, religious, or otherwise. Prior to this, the British had, to some extent, altered the modalities of Al Khalifa repression towards the indigenous Bahārna and Shi' $a$ population. Yet now it seems, as Abulhadi Khalaf argues, that the ruling family are continuing on the path of Ahmed the Conqueror, [rp12]appropriating land and engaging in plunder while diverting responsibility onto exogenous factors ${ }^{115}$.

So while the resonance of the Iranian Revolution is important, emphasising it as the causal agent in the rise of sectarian hostility validates the structures of power that perpetuate an existing conquerer-subject relationship in Bahrain, drawing on notions of prejudice in which Shi'a are seen as innately revolutionary and deviant. Indeed, the combination of the rhetoric of the Shi'a as an underclass in Bahrain, coupled with their historic discrimination, raises the issue of whether or not it is logically defensible to focus on the Iranian Revolution as a motivator of unrest. While is understandable that the Revolution [rp13]has attracted much attention, as it revised the US and European foreign policy to Iran, this transnationally deterministic paradigm has facilitated 
uncritical analyses seen through the prism of Atlantic-centric security concerns.

\section{BIBLIOGRAPHY}

Al Hasan, H.T., 'The role of Iran in the failed coup of 1981: The IFLB in Bahrain', Middle East Journal, vol. 65, no. 4, 2011, pp. 603-617 $<$ https://www.jstor.org/stable/41342743?seq=1\#page_scan_tab_contents $><10.2307 / 413$ 42743> [accessed 14 November 2016].

AlShehabi, O.H., 'Contested modernity: Divided rule and the birth of sectarianism, nationalism, and absolutism in Bahrain', British Journal of Middle Eastern Studies, vol. 44, no. 3, 2016, pp. 1-23.

Ascione, G., 'Unthinking modernity: Historical-sociological, Epistemological and logical pathways', Journal of Historical Sociology, vol. 27, no. 4, 2013, pp. 463-489.

Bahri, L., 'The Socioeconomic Foundations of the Shiite Opposition in Bahrain', Mediterranean Quarterly, vol. 11, no. 3, 2000, pp. 129-143.

Bassiouni, M. C., Rodley, N., Al-Awadhi, B., Kirsch, P., \& Arsanjani, M. H. (2011). Report of the Bahrain Independent Commission of Inquiry [BICI Report], BICI, Manama. Retrieved from www.bici.org.bh/BICIreportEN.pdf, (accessed on November 23). 
Barros, R., 'Courts Out of Context : Authoritarian Sources of Judicial Failure in Chile (1973-1990) and Argentina (1976-1983)', in Rule by Law : the Politics of Courts in Authoritarian Regimes, ed. by Tom Ginsburg and Tamir Moustafa. New York, Cambridge University Press, 2008, pp. 156-179.

Brons, L., 'Other, an Analysis', Transience, vol. 6, no. 1, 2015, pp. 69-91.

Commins, D., The Gulf States, a Modern History, I.B. Tauris, p. 234

Davenport, C., 'State repression and the tyrannical peace', Journal of Peace Research, vol. 44, no. 4, 2007, pp. 485-504, 10.1177/0022343307078940, (accessed 17 November 2016).

Franklin, R., Migrant labor and the politics of development in Bahrain (MERIP, 2016), http://www.merip.org/mer/mer132/migrant-labor-politics-developmentbahrain?ip_login_no_cache=a7ae599f50b951b5145fca37baa546b4\#_12, (accessed 13 November 2016).

Fuccaro, N., Histories of city and state in the Persian Gulf, [n.p.]: Cambridge University Press, 2009.

Gengler, J., Bahrain's Sunni Awakening, Middle East Report, 2012, http://www.merip.org/mero/mero011712, (accessed 13 November 2016).

Gause, G. III., F, 'Revolutionary Fevers and Regional Contagion: Domestic Structures and the "Export" of Revolution in the Middle East', Journal of South Asian and Middle Eastern Studies, vol. 14, no. 3, 1991, pp. 1-23. 
Haddad, F., 'Sectarian Relations before "Sectarianization" in pre-2003 Iraq', in N. Hashemi and D. Postel (eds), Sectarianization, London, Hursty \& Company, pp. 101 122.

Hausknecht, M., 'The Authoritarian Reflex', Dissent, vol. 54, no. 1, 54, 2011, pp. 14-16 doi: 10.1353/dss.2007.0008, (accessed 15 November 2016).

Herb, M., The Wages of Oil: Parliaments and Economic Development in Kuwait and the UAE, Grand Rapids, MI, United States: Cornell University Press, 2014.

Horne, J., 'Tn Tn Ttn and Torture in Bahrain Puncturing the Spectacle of the "Arab Spring",, in A. Shehabi \& M. Jones (eds.), Bahrain's Uprising: Resistance and Repression in the Gulf, London, Zed Books Ltd, 2015.

Hughey, M. W., 'The Five I's of Five-O: Racial Ideologies, Institutions, Interests, Identities, and Interactions of Police Violence', Critical Sociology, vol. 41, no. 6, 2015, pp. 857-871, doi: 10.1177/0896920515589724.

Jones, M.O., Methods of Repression in Bahrain During the 20th and 21st century: from the Civil List to Social Media. PhD diss., Durham University, 2016.

Jones, M.O., 'Saudi Intervention, Sectarianism, and De-Democratization in Bahrain's Uprising', in T. Davies, H. E. Ryan , A. M. Peña (eds.), Protest, Social Movements and Global Democracy Since 2011: New Perspectives (Research in Social Movements, Conflicts and Change, vol. 39) Emerald Group Publishing Limited, 2016, pp. 251 - 279.

Jones, J., and Ridout, N., Oman, culture and diplomacy, Edinburgh, Edinburgh University Press, 2012. 
Kamrava, M., 'The Arab spring and the Saudi-Led Counterrevolution', Orbis, vol. 56, no. 1, 2012, pp. 96-104, doi: 10.1016/j.orbis.2011.10.011.

Keddie, N. R., 'Arab and Iranian revolts 1979-2011: Influences or similar causes?', International Journal of Middle East Studies, vol. 44, no. 1, 2012, pp. 150-152, doi: 10.1017/S0020743811001309.

Khalaf, A., 'Arab reform brief: the outcome of a ten-year process of political reform in Bahrain', Arab Reform Initiative, December 2008, www.arabreform.net/sites/default/files/ARB.23_Abdulhadi_Khalaf_ENG.pdf, (accessed 30 July 2017).

Khuri, F., Tribe and State in Bahrain: The Transition of Social and Political Authority in an Arab State, Chicago, University of Chicago Press, 1981.

Lawson, F.H., 'Repertoires of Contention in Contemporary Bahrain', in Q. Wiktorowicz (ed) Islamic Activism: A Social Movement Theory Approach, Bloomington, Indiana University Press, 2004, pp. 89 - 111.

Louër, L., 'Sectarianism and Coup-Proofing Strategies in Bahrain', Journal of Strategic Studies, vol. 36, no. 2, 2013, pp. 245-260.

---, 'The Political Impact of Labor Migration in Bahrain', City \& Society, vol. 20, no. 1,2008 , pp. 32-53.

Ma'oz, M., The 'Shi 'i Crescent': Myth and Reality, Washington: The Saban Center for Middle East Policy at the Brookings Institution, 2007. 
McVeigh, R., and Rolston, B., 'From good Friday to good relations: Sectarianism, racism and the Northern Ireland state', Race and Class, vol. 48., no. 4, 2007, pp. 1-23, doi: $10.1177 / 0306396807077009$.

Pandya, S., 'Women's Shi i Ma'atim in Bahrain', Journal of Middle East Women's Studies, vol. 6, no. 2, 2010, pp. 31-58 doi: 10.2979/MEW.2010.6.2.31

Salamey, I. \& Othman, Z,m 'Shia Revival and Welayat Al-Faqih in the Making of Iranian Foreign Policy', Politics, Religion \& Ideology, vol. 12, no. 2, 2011, pp. 197-212, DOI: $10.1080 / 21567689.2011 .591983$

Schumacher, I.A., Ritual devotion among Shi'i in Bahrain, PhD Thesis edn, London: University of London, 1987.

Said, E., Covering Islam, New York, Random House.

Shahi, A., 'Thirty Years on: The Iranian Revolution and Its Impact on the Region', EInternational Relations, 2009, http:/www.e-ir.info/2009/02/14/thirty-years-on-theiranian-revolution-and-its-impact-on-the-region/, (accessed 13 November 2016).

Shehabi, A., \& Jones, M., 'The Struggle for Democracy in the Gulf', in A. Shehabi \& M. Jones (Eds.), Bahrain's Uprising: Resistance and Repression in the Gulf, London: Zed Books Ltd, 2015, pp. 1-39.

Smith, K.D, 'Royal Factions Ruling Strategies and Sectarianism in Bahrain', in Sectarian Politics in the Persian Gulf, in L. Potter (ed), Oxford: Oxford University Press, 2014, pp. 143-178. 
Terhalle, M, 'Are the Shi'a rising?', Middle East Policy, vol. 14, no. 2, 2007, pp. 69-83.

Valeri, M., 'Contentious Politics in Bahrain: Opposition Cooperation between Regime Manipulation and Youth Radicalisation', in H. Kraetzschmar (ed), The Dynamics of Opposition Cooperation in the Arab World: Contentious Politics in Times of Change, London, Routledge, 2012, pp. 129-149, p

Wehrey, Frederic M, Sectarian Politics in the Gulf: From the Iraq War to the Arab Uprisings, New York, NY, United States: Columbia University Press, 2014.

\footnotetext{
${ }^{1}$ Bahārna describes an ethnoreligious group of people inhabiting the islands of Bahrain and the Eastern Arabian Peninsula

${ }^{2}$ E Said, Covering Islam, Random House; New York, p. 28.

${ }^{3}$ For more on the construction of this Iranian threat during the 2011 Uprisings, see J. Horne, 'Tn Tn Ttn and Torture in Bahrain Puncturing the Spectacle of the "Arab Spring", in A. Shehabi \& M. Jones (eds.), Bahrain's Uprising: Resistance and Repression in the Gulf, London, Zed Books Ltd, 2015.

${ }^{4}$ M. C. Bassiouni, N. Rodley, B. Al-Awadhi, Kirsch, P., \& M.H. Arsanjani, Report of the Bahrain Independent Commission of Inquiry [BICI Report], BICI, Manama. Retrieved from www.bici.org.bh/BICIreportEN.pdf, (accessed on November 2016). Referred to hereon as 'BICI Report'.

${ }^{5}$ See for example J. Horne, 2015.

${ }^{6}$ See, for example, M.O. Jones, 'Saudi Intervention, Sectarianism, and De-Democratization in Bahrain's Uprising', in T. Davies , H.E. Ryan \& A. M. Peña (eds), Protest, Social Movements and Global Democracy Since 2011: New Perspectives (Research in Social Movements, Conflicts and Change, vol 39, Emerald Group Publishing Limited, 2016, pp. 251 - 279, or K. Smith, 'Royal Factions Ruling Strategies and Sectarianism in Bahrain', in L. Potter (ed.), Sectarian Politics in the Persian Gulf, Oxford: Oxford University Press, 2014, pp. 143-178.

${ }^{7}$ Many of the British archival documents from this period have only become available in the last ten years.

${ }^{8}$ L. Brons, 'Other, an Analysis', Transience, vol. 6, no. 1, 2015, p. 77.

${ }^{9}$ S. Hunter, The Real Causes of Iraq's Problems, LobeLog, 2014, http://lobelog.com/2014-06-the-realcauses-of-iraqs-problems/, (accessed 13 November 2016).

${ }^{10}$ J. Gengler, Bahrain's Sunni Awakening, Middle East Report, 2012, http://www.merip.org/mero/mero011712, (accessed 13 November 2016).

${ }^{11}$ V. Nasr, The Shi Revival: How Conflicts within Islam Will Shape the Future, W.W. Norton \& Company, London, e-book.

${ }^{12}$ In this case, the modality of repression can be defined as the type of methods and modes of implementation used in the pursuit of damaging or destroying political opposition.

${ }^{13}$ M. Terhalle, 'Are the Shi 'a rising?', Middle East Policy, vol. 14, no. 2, 2007, p. 71.

14 A. Shahi, 'Thirty Years on: The Iranian Revolution and Its Impact on the Region', E-International Relations, 2009, http://www.e-ir.info/2009/02/14/thirty-years-on-the-iranian-revolution-and-itsimpact-on-the-region/, (accessed 13 November 2016).

15 J. Jones and N. Ridout, Oman, Culture and Diplomacy, Edinburgh, Edinburgh University Press, 2012)

${ }^{16}$ M. Kamrava, 'The Arab spring and the Saudi-Led Counterrevolution', Orbis, vol. 56, no. 1, 2012, p. 97, doi: 10.1016/j.orbis.2011.10.011.

${ }^{17}$ D. Commins, The Gulf States, a Modern History, I.B. Tauris, p. 234

18 M. Ma'oz, 'The 'Shi'i Crescent': Myth and Reality', November 2007, p. 27.

${ }^{19}$ H.T. Al Hasan, 'The role of Iran in the failed coup of 1981: The IFLB in Bahrain', Middle East Journal,
} 
vol. 65 , no. 4, 2011, pp. 603-617

$<$ https://www.jstor.org/stable/41342743?seq=1\#page_scan_tab_contents $><10.2307 / 41342743>$

(accessed 14 November 2016).

20 Ibid.

${ }^{21}$ For exceptions to this trend see, for example, Y. Guzansky, B. Berti, 'Is the New Middle East Stuck in Its Sectarian Past? The Unspoken Dimension of the "Arab Spring", Orbis, vol. 57, no. 1, 2013, pp. 135-151, ISSN 0030-4387, http://dx.doi.org/10.1016/j.orbis.2012.10.009. Guzansky and Berti argue that 'Within Bahrain, however, the impact of the Iranian revolution on the local Shiite community was not highly significant' (http://www.sciencedirect.com/science/article/pii/S0030438712000828)

${ }^{22}$ Gause, G. III., F, 'Revolutionary Fevers and Regional Contagion: Domestic Structures and the "Export" of Revolution in the Middle East', Journal of South Asian and Middle Eastern Studies, vol. 14, no. 3, 1991, p. 3.

${ }^{23}$ I. Salamey \& Z.Othman, 'Shia Revival and Welayat Al-Faqih in the Making of Iranian Foreign Policy', Politics, Religion \& Ideology, vol. 12, no. 2, 2011, pp. 197-212, DOI: 10.1080/21567689.2011.591983

${ }^{24}$ See for example, T.C. Jones (2006), 'Rebellion on the Saudi Periphery: Modernity, marginizaltion and the Shia Uprising of 1979', International Journal of Middle East Studies, vol. 38, no. 2, pp. 213-233. doi: $10.1017 / \mathrm{S} 0020743806412320$

${ }^{25}$ L. Louer, 'The Limits of Iranian Influence Among Gulf Shi`a', CTC Sentinel, 2009, https:/ctc.usma.edu/v2/wp-content/uploads/2010/06/Vol2Iss5-Art5.pdf

${ }^{26}$ I. A. Schumacher, Ritual devotion among Shi'i in Bahrain, PhD Thesis, London School of Economics: University of London, 1987, p. 18.

27 H.B. Walker, The Shi'a in Bahrain, 26 October 1980, FCO8/3489, TNA

28 Ibid.

29H.B. Walker, 'Bahrain after the BICI' (Conservative Middle East Council, 2011), $<$ http://cmec.org.uk/blog/bahrain-after-the-bici/> [accessed 13 November 2016]. See http://bna.bh/portal/en/news/483548?date=2014-07-7 for quote

${ }^{30}$ F Gregory Gause, III, 'Revolutionary Fevers...'

${ }^{31}$ S. Pandya, 'Women's Shi i Ma'atim in Bahrain', Journal of Middle East Women's Studies, vol. 6, no. 2, 2010, pp. 31-58 doi: 10.2979/MEW.2010.6.2.31

${ }^{32}$ H.B. Walker, Annual Review 1979, TNA

${ }^{33}$ H.B. Walker, Telegram 82, 27 April 1980, FCO8/3489, TNA.

${ }^{34}$ H.B. Walker, Bahrain: Annual Review for 1980, 10 February 1981, FCO8/3894, TNA.

${ }^{35}$ K.J. Passmore, Cable to C.E.J. Wilton, 14 May 1980, FCO8/3489, TNA.

${ }^{36}$ Copson, Telegram No 165, 16 September, 1981, FCO8/3893, TNA.

${ }^{37}$ M.O. Jones, Methods of repression in Bahrain during the 20th and 21st century: from the civil list to social media. PhD diss., Durham University, 2016.

${ }^{38}$ R. McVeigh, 'Sectarianism in Northern Ireland: Towards a definition in law' 2014.

39 McVeigh and Rolston argue in their work on Northern Ireland that sectarianism has been undertheorised generally, and is 'a racism'. This conceptualisation has not been common, yet the study of the Middle East can often be slow to draw on academic contexts beyond oil and shaykhs (Foley, 2010). McVeigh and Rolston state that we 'know enough about racism now to realise that it is not a natural outcome of skin colour differences, but a social process that selects skin colour or some other real, exaggerated or imaginary characteristic as the mark of difference'. In some contexts, religion can acquire the 'rigidity which skin colour has had elsewhere'. In Ireland for example, 'Catholics were deemed to be inherently lesser - lazy, unintelligent, violent and rebellious - while the coloniser bore none of these characteristics'. Robbie McVeigh and Bill Rolston, 'From good Friday to good relations: Sectarianism, racism and the Northern Ireland state', Race \& Class, iv, 48 (2007), 1-23. $<$ http://rac.sagepub.com/content/48/4/1.refs $><10.1177 / 0306396807077009>$ [accessed 17 November 2016].

${ }^{40}$ F. Haddad, 'Sectarian Relations before "Sectarianization” in pre-2003 Iraq', in N. Hashemi and D. Postel (eds), Sectarianization, London, Hursty \& Company, pp. $101-122$.

${ }^{41}$ There are more contemporary efforts to theorise sectarianism. See for example, Fanar Haddad, ' "'Sectarianism" and Its Discontents in the Study of the Middle East', Middle East Journal, vo. 71, no. 3, summer 2017, https://doi.org/10.3751/71.3.12 and J. Gengler, 'Understanding Sectarianism in the Persian Gulf', in Sectarian Politics in the Persian Gulf, Lawrence G. Potter, (ed)., Hurst/Oxford University Press, 2014.

${ }^{42}$ C. Daly, 1921 Records of Bahrain 1893 - 1923, vol. 3, Slough, Archive Editions, 1993, p. 674 
${ }^{43}$ Ascione, G., 'Unthinking modernity: Historical-sociological, Epistemological and logical pathways', Journal of Historical Sociology, vol. 27, no. 4, 2013, pp. 463-489.

44 AlShehabi, O.H., 'Contested modernity: Divided rule and the birth of sectarianism, nationalism, and absolutism in Bahrain', British Journal of Middle Eastern Studies, vol. 44, no. 3, 2016, pp. 1-23.

${ }^{45}$ F. Khuri, 1980.

${ }^{46}$ R. Alaaldin, 'Shi‘a Crescent: Self-fulfilling Prophecy', Open Democracy, 2015, https://www.opendemocracy.net/author/ranj-alaaldin, (accessed 14 November 2016).

${ }^{47}$ Similarly, it is not so simple as to say it is a Sunni regime persecuting a Shi' a majority. The fact that the ruling family monopolise positions of influence, and the parliament have no real executive authority, suggests that discrimination emanates more readily from a tribal exclusivity than any broad-based popular sectarian animosity.

${ }^{48}$ This category is one of three that Schumacher identifies. She is certainly not arguing that all Sunni feel this way.

${ }^{49}$ M.O. Jones, Here's Looking at YouTube. Neoliberalism, Political Violence, and Racialised CounterSpace in Bahrain, MSc Dissertation, 2010 p. 28.

${ }^{50}$ I. A. Schumacher, p. 33.

${ }^{51}$ Jiwon Choi, University of Exeter Gulf Conference 2017, PhD Thesis,

52 Schumacher, p. 30.

53 Ibid. p. 33.

${ }^{54}$ Anon, 'Selections from the Records of the Bombay Government' [23] (60/733), British Library:

India Office Records and Private Papers, IOR/R/15/1/732, in Qatar Digital Library

$<$ http://www.qdl.qa/en/archive/81055/vdc_100022870191.0x00003d > [accessed 27 July 2015]

${ }^{55}$ In the 1920s, Major Daly submitted an abridged list of complaints to the Political Resident in Bushire. Visit the QL holdings for full details: 'File 9/4 Bahrain Reforms. Introduction of Reforms in Bahrain' [6r] (28/224), British Library: India Office Records and Private Papers, IOR/R/15/2/131, in Qatar Digital Library < http://www.qdl.qa/en/archive/81055/vdc_100023403812.0x00001d > (accessed 17 November 2016).

${ }^{56}$ Translation of a petition presented to the political resident on $21^{\text {st }}$ December 1921 by a large deputation of Bahrain subjects. Records of Bahrain 1820 - 1960, vol. 4, p. 665.

${ }^{57}$ Herb, The Wages of Oil...

${ }^{58}$ C.G. Prior, 29 June 1929, Records of Bahrain 1820 - 1960, vol. 4, p. 551.

${ }^{59}$ Belgrave, 5 January 1932, Papers of Charles Dalrymple-Belgrave...

${ }^{60 \prime}$ L. Louër,'The Political Impact of Labor Migration in Bahrain', City \& Society, vol. 20, no. 1, 2008, pp.

32-53.

${ }^{61}$ Belgrave, 6 October, 1953.

${ }^{62}$ The British, for example, did not like to recruit Bahārna on account of their short height and bad eyesight.

${ }^{63}$ A. Parsons, 22 October 1968, 'Bahrain National Guard', Records of Bahrain 1966 - 1971, Slough, Archive Editions, 2006, p. 522.

${ }^{64}$ L. Louër, 'Sectarianism and Coup-Proofing strategies in Bahrain', Journal of Strategic Studies, vol. 36, no. 2, 2013, pp. 245-260.

${ }^{65}$ Ibid.

${ }^{66}$ Louër, 'Limits of Iranian...'

${ }^{67}$ In this regard, their oppression, and ability to lobby the British, already made them an important political actor in the early 1900s as opposed to passive, disparate subjects. Their Shi'a identity, while obviously, an important aspect of identity, became a basis for the recourse to protection, rather than an inevitable aspect of disloyalty. It was only the persecution that forced the Bahāarna to threaten to the British that they should seek recourse from Persia for protection.

${ }^{68}$ C. Davenport, 'State repression and the tyrannical peace', Journal of Peace Research, vol. 44, no. 4, 2007, pp. 485-504, 10.1177/0022343307078940, (accessed 17 November 2016).

${ }^{69}$ Hughey, M. W., 'The Five I's of Five-O: Racial Ideologies, Institutions, Interests, Identities, and Interactions of Police Violence', Critical Sociology, vol. 41, no. 6, 2015, pp. 857-871, doi: $10.1177 / 0896920515589724$.

70 'Advisory Roles of the UK and Certain Others Countries in the Persian Gulf States', US Embassy Manama, 20 February 1975,https://www.wikileaks.org/plusd/cables/1975MANAMA00217_b.html, (accessed 5 October 2015).

71 W.R. Tomkys, Internal Political Situation Bahrain 1982, 10 April 1982, FCO 8/4332, TNA 
72 R.M. Tesh, Bahrain Internal, 1 March 1975, FCO8/2415, TNA

73 R.M. Tesh, Bahrain: Annual Review for 1973, FCO8/2181, TNA.

74 R.M.Tesh, Bahrain: Internal, 17 December 1973, FCO8/1975, TNA

75 R.M. Tesh, Bahrain Internal, 18 November 1973, FCO 8/1975.

76 R.M. Tesh, Bahrain Internal, 1 July 1974, FCO8/2180, TNA.

77 R.M. Tesh, Form at a Glance (FAAG), 24 June 1974, FCO8/2180, TNA

78 R.M. Tesh, 8 October 1974, FCO8/2180, TNA.

${ }^{79}$ R. Tomkys, First Impressions, 4 February 1982, FCO 8/4332, TNA.

${ }^{80}$ Annual Review 1972

${ }^{81}$ It is interesting to note that, contrary to what Louer recorded too, HDAC Miers notes that there had never been any Shi'a in the BDF between its creation and 1982.

${ }^{82}$ M. O. Jones, 'Saudi Intervention...'

${ }^{83}$ Ibid.

${ }^{84}$ K.J. Passmore, Bahrain Internal, 3 December 1980, FCO8/3489, TNA.

${ }^{85}$ Ibid.

86 Ibid.

${ }^{87}$ KJ Passmore to Mr Palmer, Mr Miers - 3rd December 1980

${ }^{88}$ W.R. Tomkys, Internal Political Situation Bahrain 1982, 10 April 1982, FCO 8/4332, TNA.

${ }^{89}$ Barros, R., 'Courts Out of Context : Authoritarian Sources of Judicial Failure in Chile (1973-1990) and Argentina (1976-1983)', in Rule by Law : the Politics of Courts in Authoritarian Regimes, ed. by Tom Ginsburg and Tamir Moustafa. New York, Cambridge University Press, 2008, pp. 156-179.

${ }^{90}$ Hausknecht, M., 'The Authoritarian Reflex', Dissent, vol. 54, no. 1, 54, 2011, pp. 14-16 doi: 10.1353/dss.2007.0008, (accessed 15 November 2016).

${ }^{91}$ For more on divisive politics in this era, see M. Valeri, 'Contentious Politics in Bahrain: Opposition Cooperation between Regime Manipulation and Youth Radicalisation', in H. Kraetzschmar (ed), The Dynamics of Opposition Cooperation in the Arab World: Contentious Politics in Times of Change, London, Routledge, 2012, p. 137.

${ }^{92}$ The people's bloc refers loosely to a left-leaning political grouping that emerged in the 1973 elections.

${ }^{93}$ See for example, F.M. Wehrey, Sectarian Politics in the Gulf: From the Iraq War to the Arab Uprisings, New York, NY, United States: Columbia University Press, 2014, p. 22.

${ }^{94}$ M. Valeri, 'Contentious Politics in Bahrain...', p. 137.

${ }^{95}$ R.M. Tesh, Bahrain Internal, 6 May 1974, FCO8/2180, TNA.

${ }^{96}$ R.M. Tesh, Bahrain's First Parliament, 8 July 1974, FCO 8/2180, TNA

${ }^{97}$ R.M. Tesh, Bahrain Internal, 6 May 1974, FCO8/2180, TNA

${ }^{98}$ The Killing of al-Madani was reportedly also part of a wider plot to assassinate the rulers, just as the 1981 coup was, although this has received little attention in Bahrain's history, despite the fact it appeared to achieve more of its objectives than the 1981 coup attempt.

99 E.F.Given, Political Murder in Bahrain, 29 January 1977, FCO8/2874, TNA.

100 Ibid.

101 Ibid.

102 E.F.Given, Political Murder in Bahrain, 29 January 1977, FCO8/2874, TNA.

${ }^{103}$ Wehrey, Sectarian politics in the Gulf, p. 22.

${ }^{104}$ F. Khuri, Tribe and State in Bahrain: The Transition of Social and Political Authority in an Arab State, Chicago: University of Chicago Press, 1981.

${ }^{105}$ Bahri, L., 'The Socioeconomic Foundations of the Shiite Opposition in Bahrain', Mediterranean Quarterly, vol. 11, no. 3, 2000, pp. 130.

${ }^{106}$ Ibid.

${ }^{107}$ Khuri, Ibid.

${ }^{108}$ R. Franklin, 'Migrant labor and the politics of development in Bahrain', MERIP, 2016,

http://www.merip.org/mer/mer132/migrant-labor-politics-development-

bahrain?ip_login_no_cache=a7ae599f50b951b5145fca37baa546b4\#_12, (accessed 13 November 2016)

${ }^{109}$ Gregory Gause, 1991.

${ }^{110}$ D.E. Tatham, 'Internal Security in Bahrain', FCO File Retrieved through FOIA. See https://www.whatdotheyknow.com/request/164213/response/658369/attach/3/0544\%2013\%20Tribuna 1\%20releasable\%20material\%20290515.pdf

111 E.F. Given, Prospects for Bahrain, 5 July 1976, FCO8/2643, TNA 
${ }^{112}$ N. Fuccaro, Histories of city and state in the Persian Gulf, [n.p.]: Cambridge University Press, 2009.

${ }^{113}$ Schumacher, p. 73

${ }^{114}$ F.H. Lawson, 'Repertoires of Contention in Contemporary Bahrain', in Q. Wiktorowicz (ed) Islamic Activism: A Social Movement Theory Approach, Bloomington, Indiana University Press, 2004, pp. 89 -111 .

${ }^{115}$ Abdulhadi Khalaf, Online Comment. See https://marcowenjones.wordpress.com/2012/12/31/oppression-of-bahrain-subjects-by-the-rulingfamily-in-bahrain-in-the-early-1900s-the-full-list/ 